Int. J. Dev. Biol. 61: 257-265 (2017)

doi: $10.1387 / \mathrm{ijdb} .160232 \mathrm{nb}$

\title{
Floor plate descendants in the ependyma of the adult mouse Central Nervous System
}

\author{
SOPHIE KHAZANOV, YAEL PAZ, AMIT HEFETZ, BEN J. GONZALES, YAARA NETSER, \\ ABED A. MANSOUR* and NISSIM BEN-ARIE* \\ Department of Cell and Developmental Biology, Institute of Life Sciences, \\ Hebrew University of Jerusalem, Jerusalem, Israel
}

\begin{abstract}
During embryonic development of the Central Nervous System (CNS), the expression of the bHLH transcription factor Nato3 (Ferd3I) is unique and restricted to the floor plate of the neural tube. In mice lacking Nato3 the floor plate cells of the spinal cord do not fully mature, whereas in the midbrain floor plate, progenitors lose some neurogenic activity, giving rise to a reduced population of dopaminergic neurons. Since the floor plate is considered to be disintegrated at the time of birth, Nato3 expression was never tested postnatally and in adult mice. Here, we utilized a Nato3 knockout mouse model in which a LacZ reporter precisely replaced the coding region under the endogenous regulatory elements, so that its expression recapitulates the spatiotemporal pattern of Nato3 expression. Nato3 was found to be expressed in the CNS throughout life in a highly restricted manner along the medial cavities: in subpopulations of cells in the III $^{\text {rd }}$ ventricle, the cerebral aqueduct, the $\mathrm{IV}^{\text {th }}$ ventricle, the central canal of the spinal cord, and the subcommissural organ, a gland located in the midbrain. A few unifying themes are shared among all Nato3-positive cells: all are positioned in the midline, are of an ependymal type, and contact the cerebrospinal fluid (CSF) similarly to the embryonic position of the floor plate bordering the lumen of the neural tube. Taken together, Nato3 defines an unrecognized subpopulation of medial cells positioned at only one side of circular ependymal structures, and it may affect their regulatory activities and neuronal stem cell function.
\end{abstract}

KEY WORDS: Nato3, floor plate, ependyma, spinal cord, subcommissural organ

\section{Introduction}

Nato3 (Ferd3) is an evolutionarily conserved gene encoding a basic Helix-Loop-Helix (bHLH) transcription factor, which was shown to be expressed in the central nervous system (CNS) of Drosophila and mouse during embryonic development (Segev et al., 2001). Nato3 was found to be selectively expressed in the floor plate, a transient embryonic organizing center, which secretes morphogens that pattern the neural tube (Jessell, 2000). To gain insight into the biological role of Nato3 during neurogenesis, a knockout mouse model (MGI: Ferd3 ${ }^{\text {tm } 1 \text { Yono }}$ ) was generated and characterized (Ono et al., 2010). In this mutant, the coding exon and a downstream fragment were replaced by green fluorescent protein (GFP) and $\mathrm{NeO}^{R}$ encoding genes; however, GFP expression was not induced at the expense of Nato3. In the developing spinal cord, a transient defect in differentiation, but not specification, was identified for a few medially restricted markers. The effect of Nato3 deletion on the development of floor plate cells in the midbrain was much more dramatic, and led to a reduction in the neurogenic activity of the medial floor plate, due to the transcriptional suppression of proneural genes and the induction of cell cycle arrest. As a result, the number of midbrain dopaminergic neurons generated from the mesencephalic floor plate progenitors decreased in null micealready during embryogenesis (Ono et al., 2010). The importance of Nato3 to the differentiation of dopaminergic neurons and its integration into the transcriptional network regulating these processes was further

\footnotetext{
Abbreviations used in this paper: bHLH, basic Helix-Loop-Helix; BrdU, bromodeoxyuridine; CSF, cerebrospinal fluid; SCF-cN", CSF-contacting neurons; CNS, central nervous system; GFP, green fluorescent protein; qRT-PCR, quantitative real-time reverse transcription polymerase chain reaction; RT, room temperature; SCO, subcommissural organ; Shh, Sonic hedgehog.
}

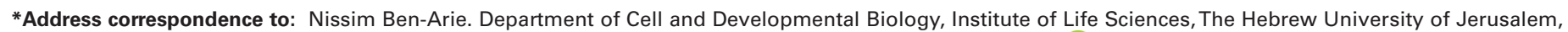
Jerusalem 91904, ISRAEL. Tel: +972-2-6584283. Fax: +972-2-6584170. E-mail: Nissim.Ben-Arie@mail.huji.ac.il (iD) http://orcid.org/0000-0001-5465-7196 or

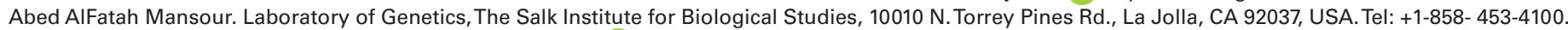
Fax: +1-858- 597-0824. E-mail: Abed.Mansour@mail.huji.ac.il iD http://orcid.org/0000-0001-9025-6998
}

Accepted: 8 July, 2016.

ISSN: Online 1696-3547, Print 0214-6282

(c) 2017 UPV/EHU Press

Printed in Spain 
confirmed by in vitro studies utilizing an inducible dopaminergic culture system (Nissim-Eliraz et al., 2013).

To gain insight into the regulation of the floor plate-specific expression of Nato3 during spinal cord development, we employed in ovo electroporation for loss- and gain-of-function analyses. An evolutionarily conserved $0.2 \mathrm{~kb}$ genomic region was found to be necessary and sufficient for floor plate-specific expression of Nato3 in vitro and in vivo, via direct binding of Foxa2, a transcription activator and effector of Sonic hedgehog (Shh) (Mansour et al., 2011). Furthermore, by assessing ectopic expression in chick, Nato3 was shown to induce ectopic, non-dividing cells that express FoxA2, a key gene in floor plate induction, differentiation, and function. Nato3 was also able to independently and indirectly downregulate $N k x 2.2$, both ectopically and in the floor plate itself (Mansour et al., 2014). During spinal cord development, the ventral-most midline cells comprise the presumptive floor plate, which also expresses genes that are later typical of p3 progenitors (e.g, Nkx2.2). However, it is only during further maturation that $N k x 2.2$ is downregulated in the floor plate and its expression shifts to the p3 domain, while in parallel, late floor plate genes (e.g., $A r x$ ) are induced, to endow the definitive floor plate fate (Ribes et al., 2010). Thus, FoxA2 induction and Nkx2.2 suppression by Nato3 may indicate that it plays a role in acquiring a definitive floor plate fate.

After seeing the effect of gain-of-function in chick, we hypothesized that Nato3 may play a mechanistic role in the maturation of floor plate cells. To test the effect of Nato3 ablation in mammals, we generated an independent Nato3 knockout mouse line (MGI: Ferd3/ $^{\text {tm1Nba }}$ ) (Mansour et al., 2014). In agreement with the data obtained from chick, in Nato3 null mice, and to a greater extent, in Nato3 null/Foxa2 heterozygous bigenic mutants, the loss-offunction affected the downregulation of $N k x 2.2$ in the floor plate and consequently, a sharp boundary was not generated between the ventro-medial floor plate cells and the bordering dorso-lateral p3 progenitors. Taken together, the data suggest that Nato3 is an important regulator in the segregation of floor plate and p3 identities, which is an essential step for establishing a mature floor plate in the embryonic spinal cord (Mansour et al., 2014).

The tissue specificity of Nato3 expression during embryogenesis and the identification of its importance for the development of the floor plate of the spinal cord and the midbrain dopaminergic neurons are evident from studies in chick and mouse. However, detailed spatial and temporal expression patterns of Nato3 during embryogenesis, the postnatal period, and adulthood were not determined, and a mouse line that faithfully recapitulates Nato3 expression has not yet been reported. Here, we took advantage of the fact that the coding region of Nato3 knockin mice we generated was precisely removed and replaced by a LacZ reporter, resulting in a clear and sensitive assay to follow Nato3 expression throughout life. Thus, simple X-gal staining provided us with a tool for mapping cells, which in the embryo are positioned only in the floor plate of the neural plate. Nato3 was found to be expressed throughout the floor plate during embryogenesis and in the midline of the adult CNS in ependymal cells lining the medial cavities. Nato3-positive cells identified an unrecognized medial subpopulation of ependymal cells in the spinal cord, the IIIrd-IV th ventricles, and in the subcommissural organ, an ependymal brain gland. Henceforth, Nato3 may have uncovered that these medial ependymal cells may be ontogenetic descendants of the embryonic floor plate.

\section{Results}

To expose at high resolution the expression pattern of Nato3 during embryonic development, we took advantage of the fact that in the knockout mice that we generated the entire coding sequence was replaced by a $L a c Z$ reporter gene, while maintaining the endogenous regulatory elements (Nato3::LacZ) (Mansour et al., 2014). Nato3 embryos of the three genotypes (Nato3 ${ }^{W T}$, Nato3 ${ }^{\mathrm{Het}}$, and $\mathrm{Nato}^{\mathrm{Nu}}{ }^{\mathrm{N}}$ ) were harvested at different developmental stages and
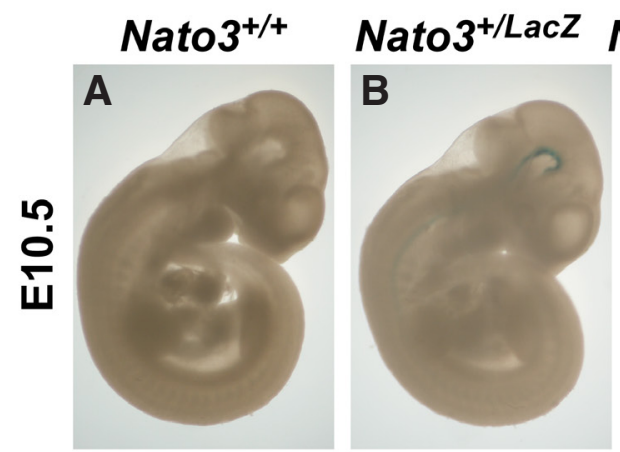

Nato3 ${ }^{\text {LacZ/LacZ }}$
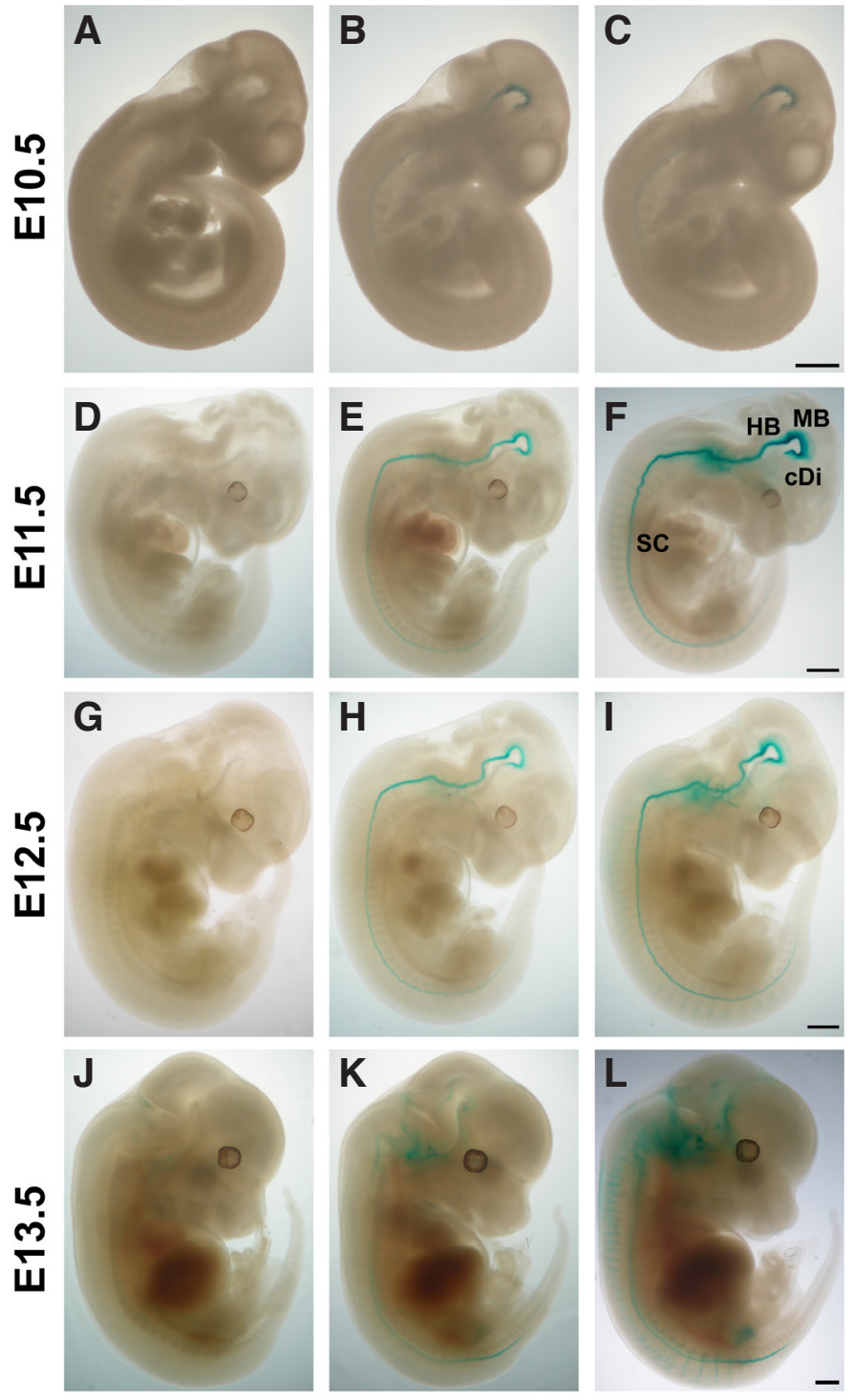

Fig. 1. Floor plate-specific expression of a Nato3 reporter during embryonic development. Embryos at various developmental stages (E10.5-13.5) and of different genotypes Nato3 $^{+/+}$wild type, Nato3 $3^{+/ L a c Z}$ heterozygous, and Nato3 LacZlLacZ null) were subjected to whole-mount $X$-Gal staining and thereafter were cleared to transparency. Staining was observed in heterozygous and more strongly in null, but not in wild-type, embryos. Staining was clearly visible in the caudal diencephalon (cDi), midbrain $(M B)$, hindbrain $(H B)$, and spinal cord $(S C)$, growing stronger in a rostral to caudal manner and with time. Scale bar, $1 \mathrm{~mm}$. 
subjected to X-gal staining. As expected, based on data on Nato3 expression per se, reporter activity was clearly detected already at embryonic day 10.5 (E10.5), when staining was stronger in the developing midbrain area, with a fainter signal spreading caudally into the developing spinal cord area. As expected, the signal was not detectable in Nato3 ${ }^{W T}$, and was stronger in Nato3 ${ }^{\text {Null }}$ when compared with $\mathrm{Nato}^{\mathrm{Het}}$ (Fig. $1 \mathrm{~A}-\mathrm{C}$ ). As the embryo developed, the staining became stronger in both areas and was continuous along the neural tube, from the caudal telencephalon via the mid- and hind-brain towards the tail (Fig. 1).

To more accurately specify the area of Nato3 expression along the dorso-ventral axis, paraffin sections from the midbrain and spinal cord levels were analyzed at various stages of embryogenesis. X-gal staining was confined to the floor plate of the neural tube, in both the emerging spinal cord and midbrain (Fig. $2 \mathrm{~A}-\mathrm{C}$ and D-F, respectively), consistent with the previously reported expression pattern (Mansour et al., 2014, Mansour et al., 2011, Ono et al., 2010). To further validate that Nato3::LacZ reporter expression faithfully recapitulates the endogenous expression pattern of Nato3, we generated an anti-Nato3 antibody to be used for immunofluorescent staining. X-gal staining of sections from Nato3 $^{\text {Het }}$ (Fig. 2 G-H) and Anti-Nato3 immunostaining of sections from Nato3 $^{W T}$ (Fig. 2 I-J) were identical and indicated floor plate specificity in both the spinal cord and midbrain. Taken together, $X$-gal staining mimicked the spatial expression of Nato3 protein, thus suggesting that $L a c Z$ activity recapitulates the endogenous expression of Nato3.

The floor plate of the spinal cord and the midbrain is considered a transient embryonic structure; thus, Nato3 expression as well as other floor markers is expected to be absent at postnatal stages. Thus, we wondered whether Nato3 expression could be detected postnatally, so that it could be utilized as a lineage tracer. To this end, newborn pups (P0) from Nato $3^{\mathrm{Het}}$ crossbreeding were stained as a whole mount by $\mathrm{X}$-gal and then sectioned for further analysis. Notably, even at P0, after the expected disintegration of the floor plate, Nato3::LacZ expression was clearly evident at the ventral midline of the spinal cord, just ventrally to the central canal (Fig. 3 A-C'). This location is reminiscent of that seen in younger embryos (Fig. 2 A-C'), where it was attributed to floor plate cells.

After observing reporter activity in the spinal cords of newborn mice, we then asked whether expression persists to adulthood. Surprisingly, few positive cells were consistently detectable even in the spinal cord of mature, six-month-old mice (Fig. 3 E, E',E'). We then hypothesized that a marker, which is not essential for specification or early differentiation of the spinal cord, but rather, is expressed at late fate acquirement stages, may also be expressed in Nato3-positive cells. Arx (Aristaless-related homeodomain transcription factor) acts with Foxa2 to convert the identity of medio-ventral cells from presumptive to definitive floor plate fate cells during spinal cord development (Cho et al., 2014, Mansour et al., 2014, Ribes et al., 2010). Immunostaining of sections from adult spinal cord against Arx generated a weak, yet consistent signal at the medial-ventral aspect of the spinal central canal (Fig. 4 ). About $17 \%$ of all cells that line the central canal ( $~ 6 / 39$ cells) were Arx-positive. Confocal colocalization analysis of Arx and DAPI revealed a strong overlap between the two signals in the indicated medial-ventral region (Fig. $4 \mathrm{C}-\mathrm{E}$ ). Staining against the early markers, Foxa2 and Shh, provided a visible signal in embryonic, but not in adult spinal cords. Whether this reflects a technical difficulty, an
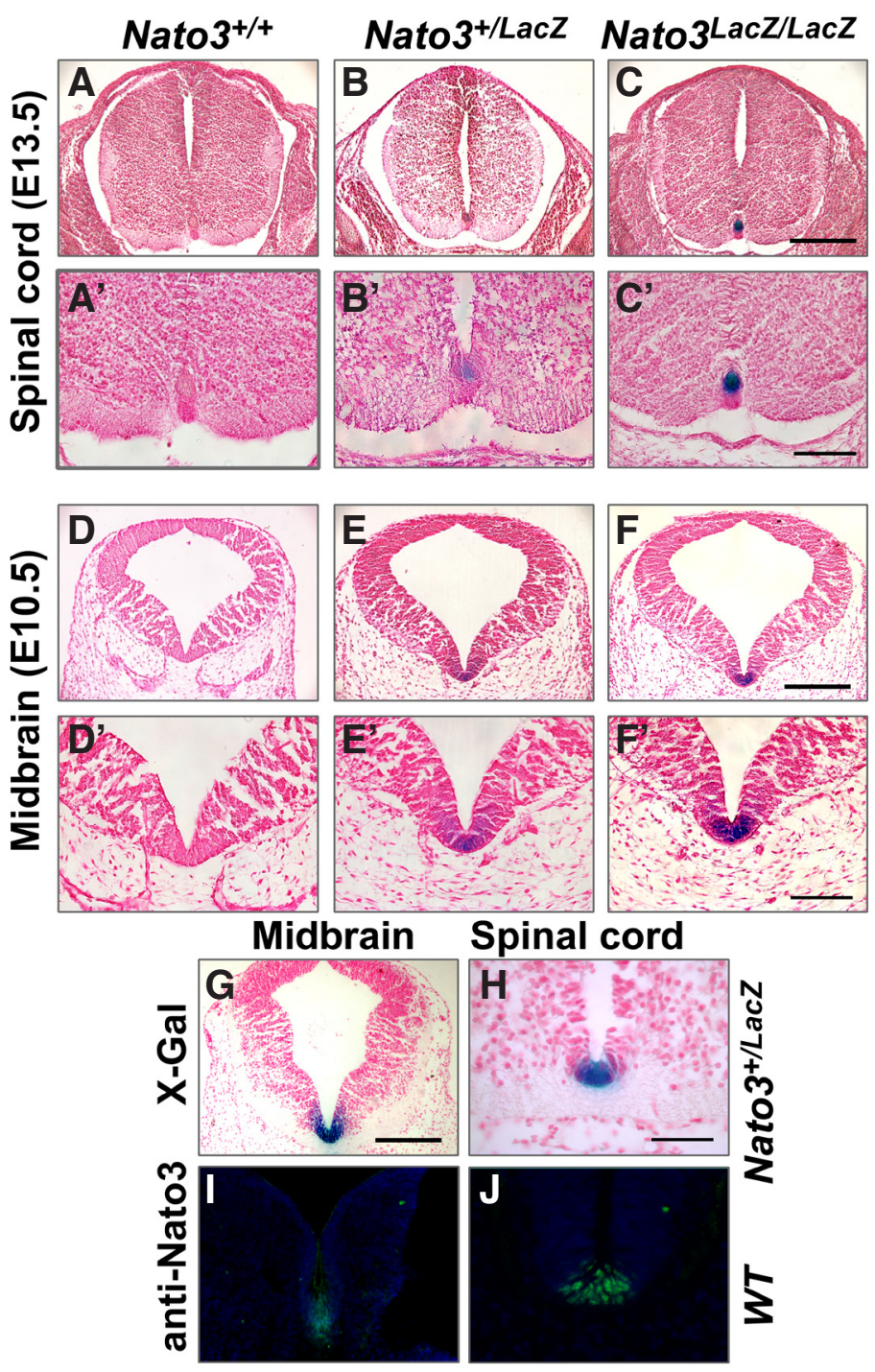

Fig. 2. Nato3 and Nato3: :LacZ reporter are expressed in the floor plate at the ventral midline of the midbrain and spinal cord. Embryos of all genotypes were harvested, stained with X-Gal, and sectioned. X-Gal staining was confined to the ventral-most cells of the spinal cord, comprising the floor plate. The intensity of the staining was higher in Nato3 Laczlacz null embryos in comparison with Nato3+/Lacz heterozygous embryos (B-B', C-C'). No staining was observed in sections from wild-type embryos (A$\left.\mathbf{A}^{\prime}\right)$. Similarly, in the midbrain, reporter expression was clearly detectable in the mesencephalic floor plate $\left(\mathbf{E}-\mathbf{E}^{\prime}, \mathbf{F}-\mathbf{F}^{\prime}\right)$. Direct labeling of wild-type embryos with antibodies against Nato3 produced results similar to X-Gal staining, showing expression in the floor plate cells of the spinal cord and mesencephalon (I-J). Scale bars, $200 \mu \mathrm{m}$ (A-C; D-F), $100 \mu \mathrm{m}\left(A^{\prime}-C^{\prime} ; D^{\prime}-F^{\prime}\right)$.

antibody-related problem, or lack of expression per se, remains to be further tested by additional antibodies.

Given the expression of Arx in the adult spinal cord, we were interested in determining whether additional embryonic floor plate markers could also be identified using an independent assay. To this end, spinal cords were dissected from two six-month-old wild type mice and cDNA was prepared separately from each animal and tested by q-RT-PCR at two dilutions in triplicate. Relatively high expression levels of Nato3, Shh, Arx, and $\beta$-Actincontrol were 
detected, whereas Foxa2 was expressed at a much lower level (Ct value $>30$ ). The PCR products were also gel separated and all products were at the expected size, indicating that these genes are transcribed in the adult spinal cord tissue (Fig. 5). Taken together, we showed that in adult mice, Nato3, as well as other embryonic floor plate markers such as Arx, Shh, and to a lower extent Foxa2 maintain their expression in the ventro-medial cells around the spinal central canal. These data imply that cells comprising the embryonic caudal floor plate have descendants that exist in the spinal cord throughout life.

During embryogenesis, Nato3 is continuously expressed in the
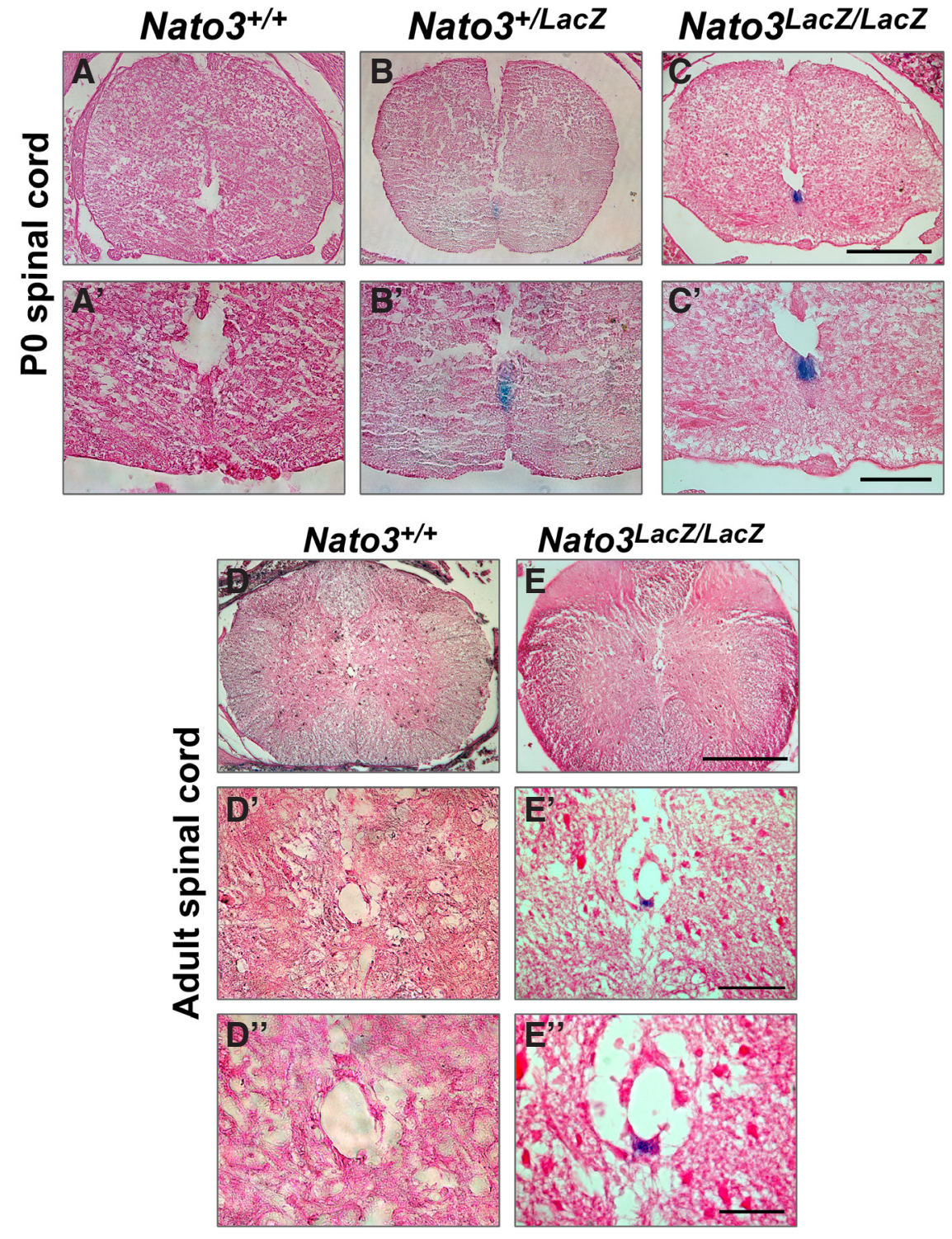

Fig. 3. Postnatal expression of Nato 3 in the spinal cord. Spinal cords were harvested from mice of three genotypes, stained by X-Gal, and sectioned. At PO(A-C'), whereas wild-type pups exhibited no $X$-Gal staining $\left(\mathbf{A}-\mathbf{A}^{\prime}\right)$, in null and heterozygous mice $X$-Gal-positive cells located ventrally and juxtaposed to central canal were clearly seen, and the intensity of the staining was stronger in null than in heterozygous mice (B-B', C-C'). In adult mice (D-E"), the spinal cord of null (E, E', E"), but not wild-type (D, $\left.\mathbf{D}^{\prime}, \mathbf{D}^{\prime \prime}\right)$ mice contained a few blue cells, which reside at the ventral border of the central canal. Scale bars, $500 \mu \mathrm{m}(A-C ; D-E), 200 \mu \mathrm{m}\left(A^{\prime}-C^{\prime} ; D^{\prime}-E^{\prime}\right)$ and $50 \mu \mathrm{m}\left(D^{\prime \prime}-E^{\prime \prime}\right)$. ventro-medial region of the CNS along the caudal telencephalonmidbrain-hindbrain to the tail (Fig. 1). Given the postnatal expression of Nato3 in the spinal cord, we reasoned that the high sensitivity of the Nato3::lacZ reporter may enable us to also map the Nato3positive cells in adult brain, if expression exists, in accordance with our hypothesis that floor plate descendants survive to adulthood. Consequently, we examined brains harvested from mice of the three genotypes at various postnatal time points: P0, P7, P14, P21, and adult, using whole-mount $\mathrm{X}$-gal staining and paraffin sectioning.

Nato3 reporter expression was indeed depicted in a medially restricted manner in the brains of heterozygous ( $\left.\mathrm{Nato}^{+/ L a c Z}\right)$ and null (Nato3 $\left.{ }^{\text {LacZLLacZ }}\right)$, but not wild-type $\left(\mathrm{Nato}^{+/+}\right)$ mice at all time points from PO to adulthood (Fig. 6). Looking first at the caudal brain, we clearly observed blue cells at the medial floor of the IV ${ }^{\text {th }}$ ventricle, beneath the choroid plexus (Fig 6. A1-A9). The positive cells are localized in a narrow layer of ependymal cells in contact with the ventricle and the cerebrospinal fluid (CSF). Moving rostrally, positive cells were also found at the medial floor of the aqueduct of Sylvius, the mesencephalic/cerebral duct connecting the $\mathrm{IIId}^{\text {rd }}$ and IV ${ }^{\text {th }}$ ventricles (Fig. 6 B1-B12). As predicted, staining also appeared at the medial roof of the posterior part of the IIIrd ventricle (Fig. $6 \mathrm{C1}-12$ ). Not only the $\mathrm{III}^{\text {rd }}$ and $\mathrm{IV}^{\text {th }}$ ventricles are connected via the aqueduct, also the $\mathrm{IV}^{\text {th }}$ ventricle and the central canal of the spinal cord are anatomically contiguous. Thus, it was demonstrated here for the first time that in the postnatal and adult mouse, Nato3 is expressed in a restricted medial subset of an ependymal cell layer surrounding the contiguous CSF-filled cavities of the CNS.

Surprisingly, a detailed analysis of the postnatal coronal sections revealed an additional site of reporter expression in the subcommissural organ gland, which is situated in the $\mathrm{III}^{\text {rd }}$ ventricle and the cerebral aqueduct, subjacent to the choroid plexus and the posterior commissure (Fig.7). Staining was clear and strong in sections from $\mathrm{Nato}^{\mathrm{Null}}$ and $\mathrm{Nato}^{\mathrm{Het}}$ brains at all postnatalages we tested, but not in controls. As expected, the positive subcommissural organ cells are columnar, whereas the ependymal cells lining the cerebral aqueduct appear cuboidal. This region of Nato3 expression is distinctive, because it is not anatomically connected to the other positive sites described. To better characterize the specificity of subcommissural organ expression, we examined brains at a sagittal plane. Halved brains that underwent whole-mount X-gal staining revealed that the expression of the reporter is initiated anteriorly above the thalamic nuclei in the floor of dorsal part of the $\mathrm{III}^{\text {rd }}$ ventricle (Fig. 8A, arrow) and that it spreads posteriorly to the $\mathrm{IV}^{\text {th }}$ ventricle (Fig. 8A, arrowhead). The second half of the same brain showed X-gal-positive cells in the 

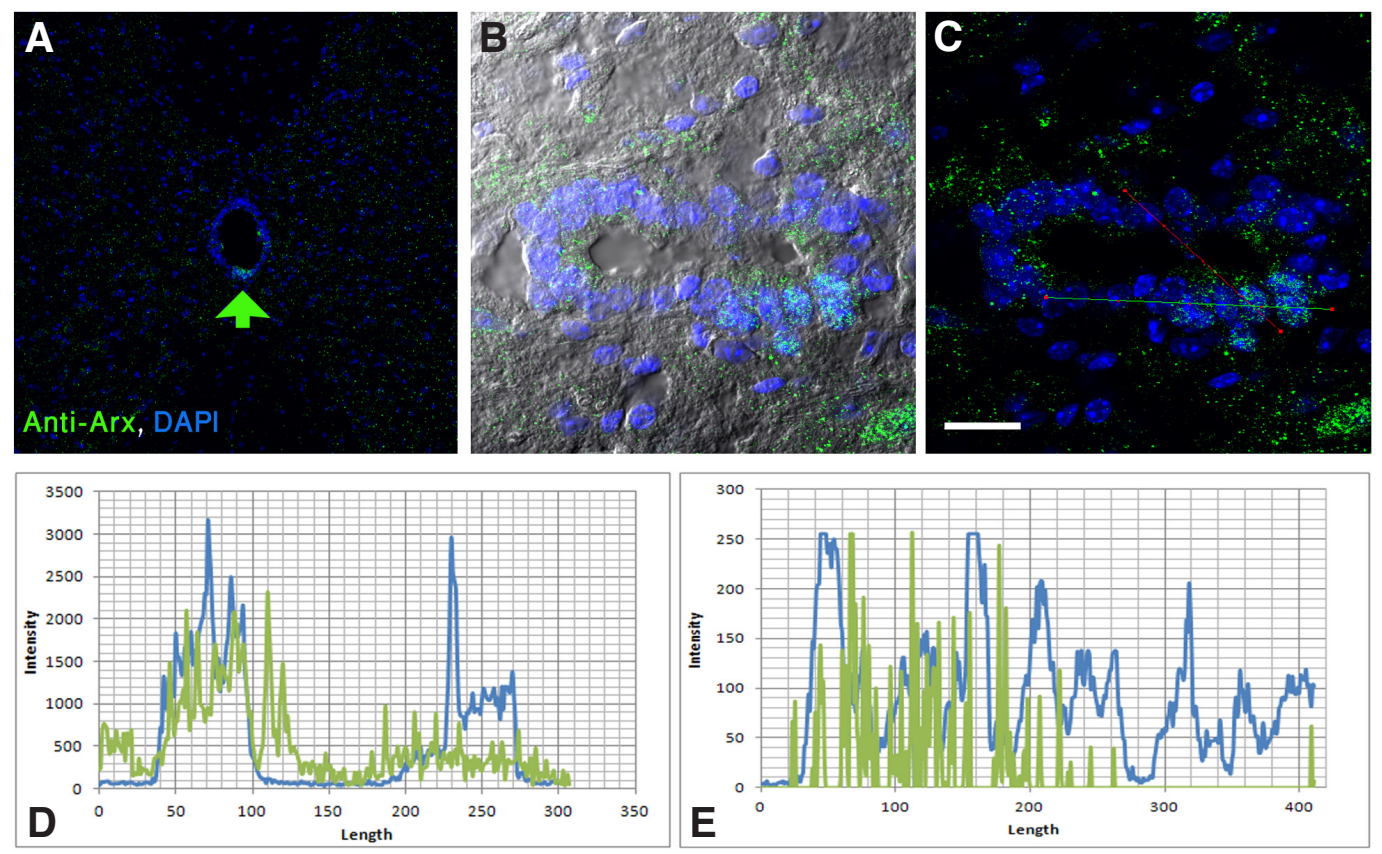

Fig. 4. Expression of Arx in the adult spinal cord. Spinal cords of adult wild-type mice were dissected and subjected to immunoflourescent staining by antiArx antibody. Staining was clearly observed in the ventro-medial cells juxtaposed to the central canal(A). Ata highermagnification of another section, the reproducibility was evident, and the nuclear localization, which was limited to a subset of ependymal cells that line the central canal, is apparent (B,C). This observation was reinforced by co-localization analysis of the sections; the red line corresponds to (D) and the green line to (E) subcommissural organ (Fig. 8B, arrow) and in the posterior part of the $\mathrm{III}^{\text {rd }}$ ventricle (Fig. 8B, asterisk). This whole-mount preparation of the mid-sagittally halved adult presented a pattern of expression similar to that seen in the coronal sections (Fig. 7) and further depicted the continuity of the signal throughout the $\mathrm{III}^{\mathrm{rd}}$ ventricle, and the aqueduct to the IV ${ }^{\text {th }}$ ventricle. To increase the resolution, we thereafter analyzed sagittal paraffin sections of adult brains that were subjected to X-gal staining (Fig. 8C-E). The subcommissural organ was strongly stained, in contrast to the contiguous posterior commissure (Fig. 8D-E).

We and others previously identified Nato3 expression in the embryonic floor plate of the neural tube, in regions that develop into the midbrain and spinal cord. In this study we took advantage of a LacZreporter placed under the endogenous regulatory elements, to broaden our knowledge about the Nato3 expression profile and to also identify for the first time positive cells in the adult mouse CNS. Positive cells, which we considered as floor plate descendants, were identified in medio-ventral structures around the CSF-containing cavities (the $\mathrm{III}^{\text {rd }}$ and IV ${ }^{\text {th }}$ ventricles and the connecting cerebral aqueduct, as well as in the continuous spinal central canal) of the adult mouse. Surprisingly, positive cells were identified specifically in the subcommissural organ gland, a medial-dorsal structure that functions throughout life.

\section{Discussion}

The knockout mouse we generated, in which the entire coding region of Nato3 was replaced by a LacZ reporter, afforded us for

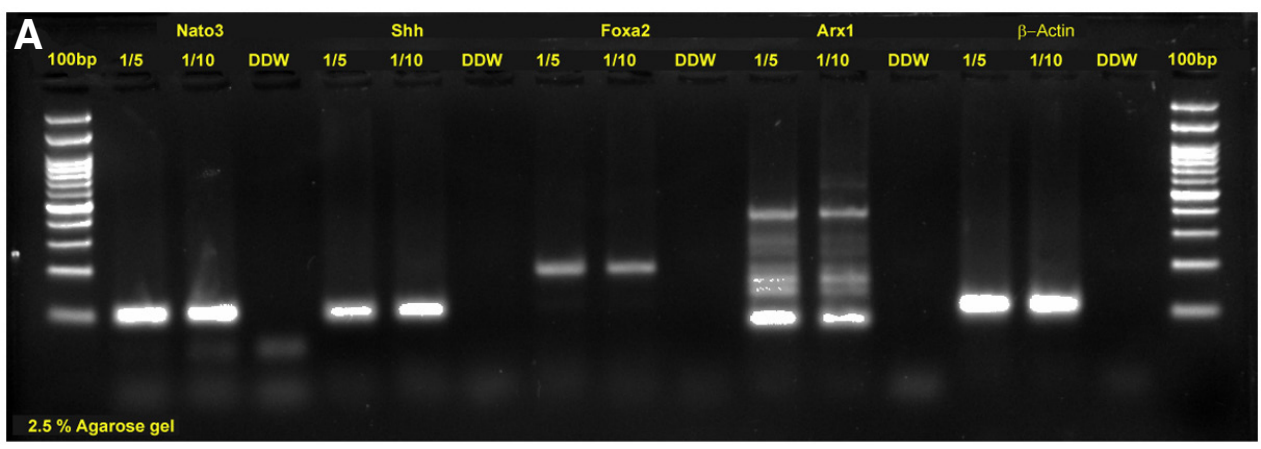

B

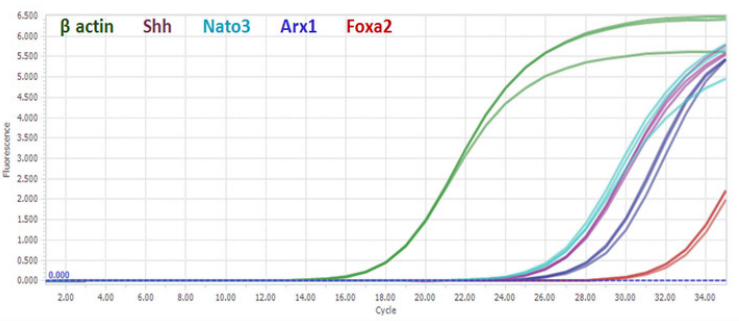

C

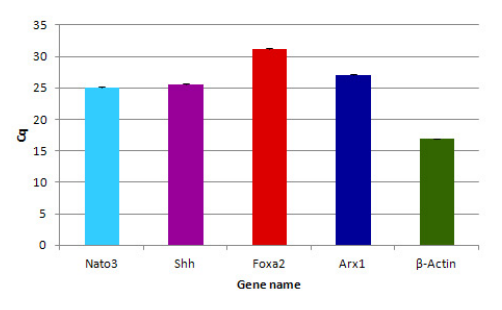

Fig. 5. Floor plate markers are expressed in the adult spinal cord. RNA from wild-type adult mice was reverse transcribed and subjected to q-RT-PCR analysis. Samples were tested for the presence of five transcripts: Nato3, Shh, Foxa2, Arx1, and $\beta$-Actin as the referencegene. (A) Gel separation confirmed that the products are of the expected size. (B) An amplification curve, which represents the average of triplicates for each of the animals, indicated the reproducibility and accumulation of products throughout the $P C R$ reaction. Cq (quantification cycle) is the cycle at which the curvature of the amplification curve is maximal, which is similar to $\mathrm{Ct}$ (cycle threshold). (C) Quantification of the expression level, as represented by the $\mathrm{Cq}$ value, where a high value indicates a lower amount of the amplification product, and the standard deviation. 
the first time the opportunity to follow, at high resolution, Nato3 expression at the cell, tissue, and whole-organism levels. Two sets of findings ensured the validity of the LacZ reporter, controlled by the endogenous regulatory elements. First, the expression of $L a c Z$ and Nato3 along the entire embryonic floor plate of the neural tube is in full agreement with previous observations (Mansour et al., 2014, Mansour et al., 2011, Ono et al., 2010). Second, the expression domains were identified immunohistochemically, using a newly raised anti-Nato3 polyclonal antibody, and the enzymatic X-gal staining overlaps, in both the embryonic spinal cord and midbrain. Moreover, we were able to use for the first time a mouse model expressing a reporter in order to determine whether Nato3, known to be important for embryonic development, also acts on the postnatal and adult mouse CNS.

Here, we have uncovered a new population of ependymal cells that have been labeled by a Nato3 reporter. The ependymal layer lines all CSF-filled cavities of the CNS, from the rostral lateral
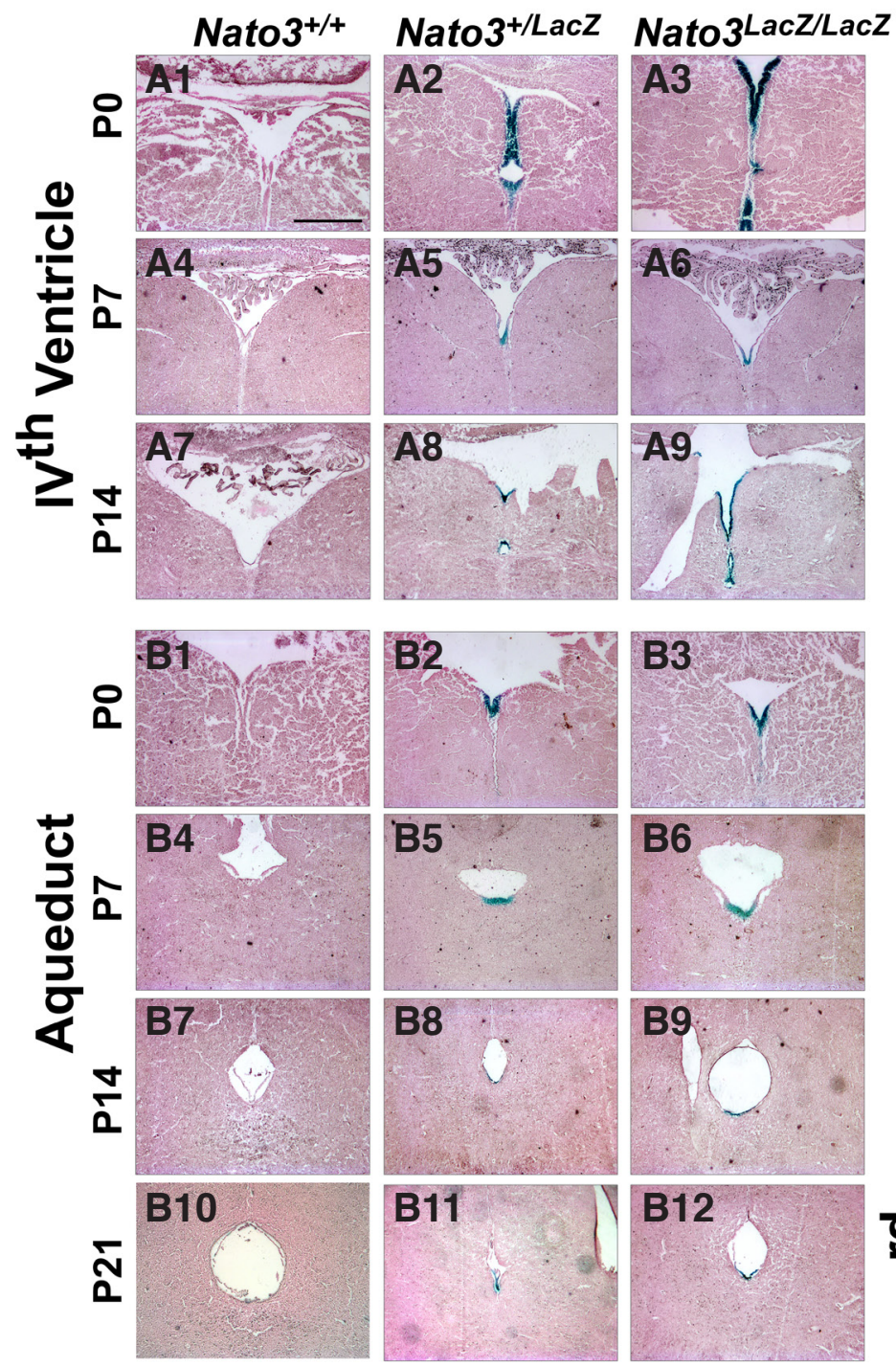

ventricles to the caudal spinal filum terminale (Del Bigio, 2010). It is composed of a single layer of ciliated cells with unique features reminiscent of neural and epithelial cells. Nato3 labels only the subset of ependymal cells that occupy the ventral midline (thus excluding the lateral ventricles), starting from the $\mathrm{II}^{\text {rd }}$ and IV ${ }^{\text {th }}$ ventricles and their connecting aqueduct, to the entire length of the central canal of the spinal cord.

In the spinal cord, Nato3 consistently highlights a small, yet specific, sub-population of 3-8 ependymal cells that are constrained to the ventral midline of the canal. Notably, Nato3 ependymal expression is initiated early in embryogenesis and is maintained throughout life. What is the embryonic origin of this ependymal layer and of the spinal central canal that it lines? Following the early wave of neurogenesis, when the spinal cord undergoes a wave of gliogenesis, the neuroepithelium at the ventricular zone, as well as the lumen it surrounds, is reduced through the process of obliteration (elimination by closure and fusion) (Fu et al., 2003). Morphological and molecular studies indicate that the dorsal half of the spinal lumen becomes reduced in size and that the remaining central canal in postnatal animals has a ventral origin. The homeodomain factor, Nkx6.1, expressed early in the ventral half of the embryonic neural tube, maintains its expression in the adult spinal cord, where it labels the entire ependymal layer (Fu et al., 2003). Shh secreted from the floor plate itself, but not from the notochord, was shown by conditional mouse mutants to be required for proper formation of the ependymal cells lining the spinal central canal (Yu et al., 2013). The ventralmost expression of Nato3 in both the embryonic floor plate and the ventral ependymal layer further support the unilateral origin of the spinal canal.

Recent studies uncovered that the different populations of CSFcontacting neurons in the mouse spinal ependyma have different

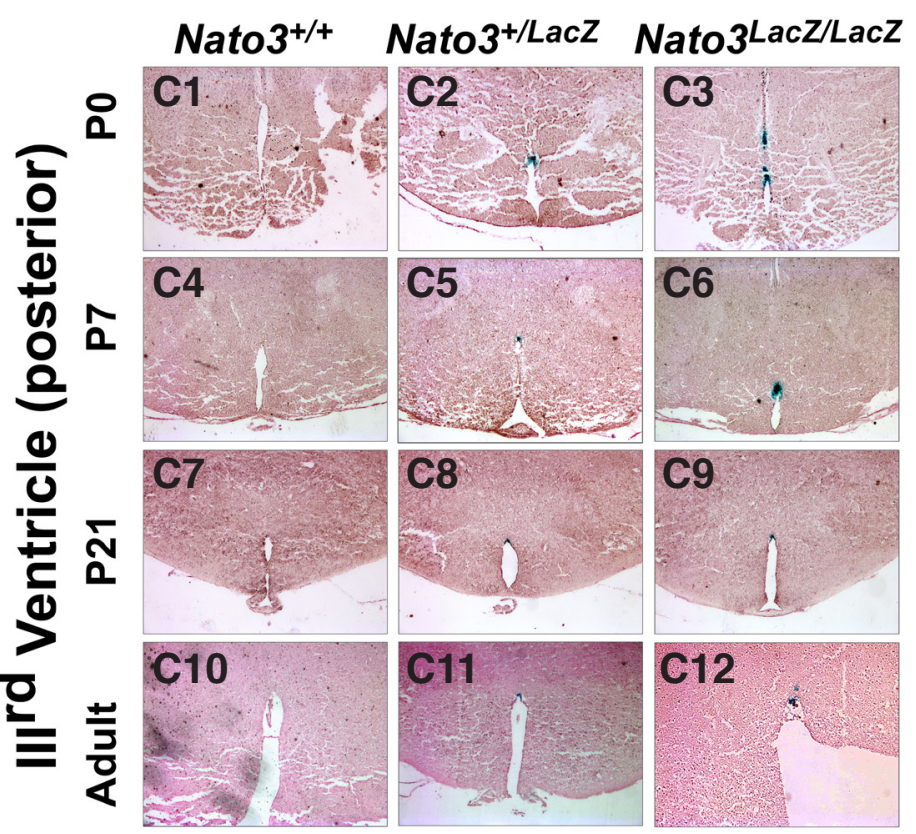

Fig. 6. Postnatal expression of Nato3 in the caudal brain. Mice of the three Nato3 genotypes were dissected at the indicated ages (P0 to adult), their brains were stained by X-Gal, and finally sectioned in a coronal plan. Whereas brains from wild-type mice did not exhibit any X-Gal staining, reporter expression was depicted in the ventral aspect of the $\mathrm{I}^{\text {th }}$ and IIIrd ventricles, as well as in the cerebral aqueduct connecting them, at all postnatal ages tested. The expressed regions were limited to the ependymal layer adjacent to the ventricles. Scale bar, $500 \mu \mathrm{m}$. 

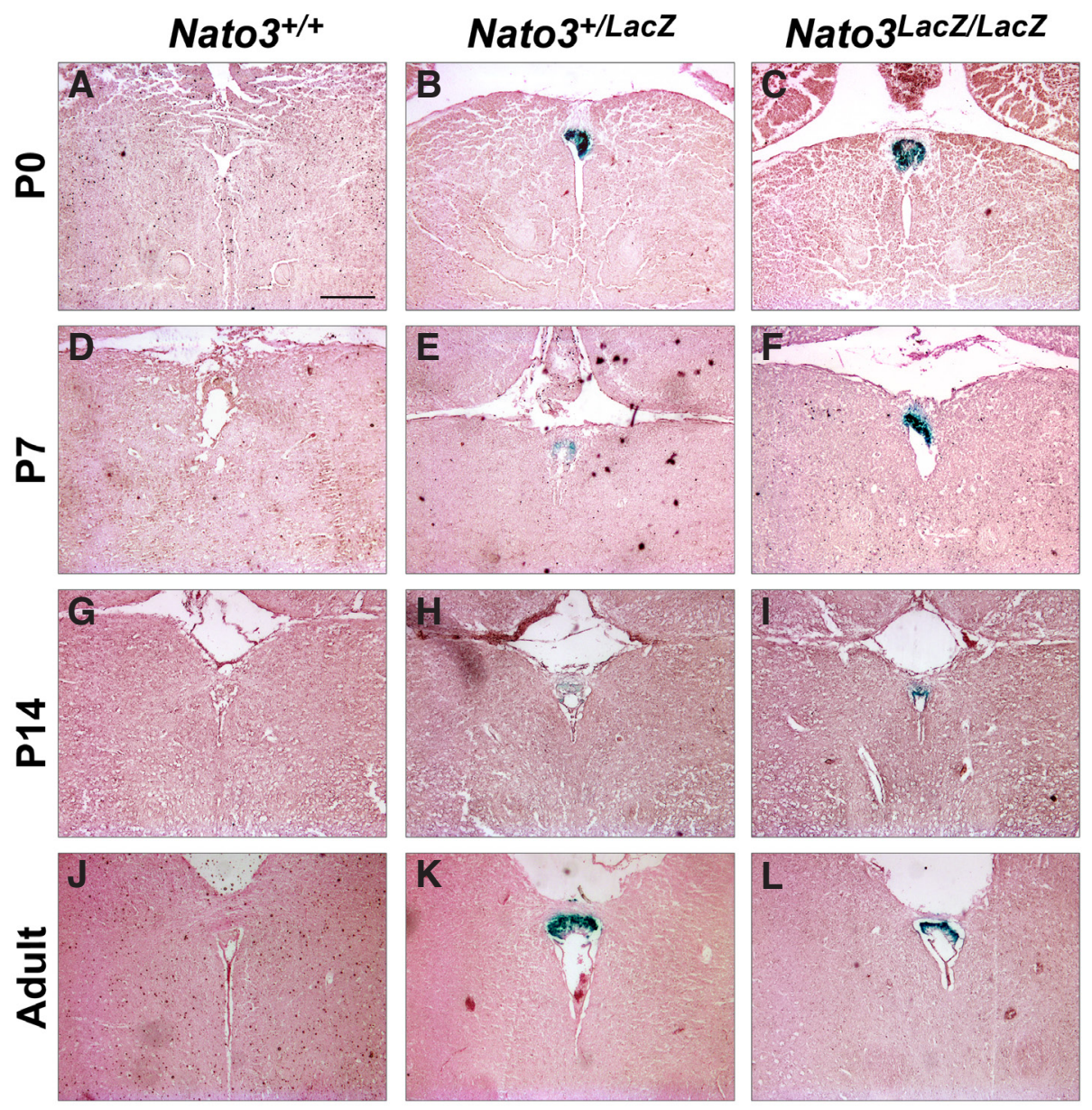

Fig. 7. Postnatal expression of Nato3 in the subcommissural organ. Mice of the three Nato3 genotypes were dissected at the indicated ages (PO to adult), their brains stained by X-Gal, and sectioned in a coronal plane. Prominent $X$-Gal staining could be observed in the subcommissural organ of Nato3 heterozygous and null and, but not with wild-type mice at all ages tested. Scale bar, $500 \mu \mathrm{m}$.

cellular origins (Petracca et al., 2016). Accordingly, most of the Gata2/3+Pkd211+ neurons in the ependymal area originate from late neurogenic events in the ventral spinal cord, during a time window previously assumed to be gliogenic. Thus, most of these CSF-contacting cells are derived from progenitors confined to the late-p2 and the dorsal half of the oligodendrogenic (pOL) domains.

A second subset of ependymal cells, termed CSF-contacting neurons (SCF-cN"), arises from cells positioned at the boundary between the p3 domain and the floor plate (Petracca et al., 2016). Whereas Nato3-positive cells are located at and around the midline, SCF-cN" cells seem to be placed laterally to the midline; hence, we hypothesize that these populations may be related. This is further supported by the fact that FoxA2 and Nkx2.2, two genes expressed early in the presumptive floor plate, are expressed at E14.5 in SCF-cN" neurons. Moreover, we showed here that embryonic floor plate markers like Shh and Arx are also expressed in the spinal cord of adult mice. Lastly, we have previously shown that Nato3 is essential for the segregation of floor plate and p3 fates, by FoxA2 transcriptional activation and a concurrent $N k x 2.2$ repression (Mansour et al., 2014). Thus, in knockout mice, where FoxA2-Nato3 signaling is affected, the borderline between the floor plate and p3 is not sharp, and cells with mixed floor plate-p3 fates are present in the floor plate (Mansour et al., 2014).

Ependymal cells in the brain and spinal cord were shown by long exposure to bromodeoxyuridine (BrdU) to undergo slow proliferation in mouse (Johansson et al., 1999) and rat (Horner et al., 2000). These and many additional studies have indicated that ependymal cells around the spinal central canal possess latent neural stem cell properties and comprise a niche of neural stem cells in adult rodents (Hamilton et al., 2009). Interestingly, in response to spinal cord injury, ependymal cell proliferation increases dramatically and give rise to astrocytes that participate in scar formation (Johansson et al., 1999). Traumatic spinal cord injury, but not demyelinating lesions, stimulates a robust, long-lasting, and long-distance wave of ependymal proliferation in the central canal (Lacroix et al., 2014). Taken together, some similarities (e.g., proliferation) exist between the embryonic ventricular zone and the adult central canal's ependyma, and between an early floor plate and the late medio-ventral Nato3-positive ependymal cells. One can only speculate that the newly identified subpopulation of Nato3-positive ependymal cells may retain some organizer capacity that affects the differentiation of the proliferating lateral cells.

A second site of Nato3 expression in the postnatal and adult mice is the subcommissural organ, the oldest phylogenetically brain gland, present throughout the chordates. The subcommissural organ is located where the dorso-caudal third ventricle connects to the aqueduct of Sylvius. It is an ependymal structure that secretes glycoproteins of high molecular mass into the ventricle, where they condense to form the Reissner's fiber. In all vertebrates, this threadlike structure gradually extends caudally from the III ${ }^{\text {rd }}$ and IV ${ }^{\text {th }}$ ventricles to the entire length of the spinal central canal of all vertebrates (Guerra et al., 2015, Rodriguez et al., 1998).

Similar ventral fiber producers in subcraniate organisms are considered descendants of the floor plate of the embryonic neural tube (Olsson, 1993). In contrast, the subcommissural organ, which is found exclusively in the vertebrate phylum, is considered exceptional, because it is dorsal, and it is thought to be produced from the dorsolateral alar plate, rather than being part of the roof plate (Olsson, 1993). Our discovery that in mouse, the subcommissural organ is Nato3 positive, may change this notion, and imply that it originates from the floor plate, thus, phylogenetically unifying the source of the fiber-secreting structures in the brain. Supporting this suggestion is the fact that both the floor plate of the developing spinal cord and the subcommissural organ are the source of secretory compounds of a related nature, such as F-spondin and subcommissural organ-spondin, respectively 

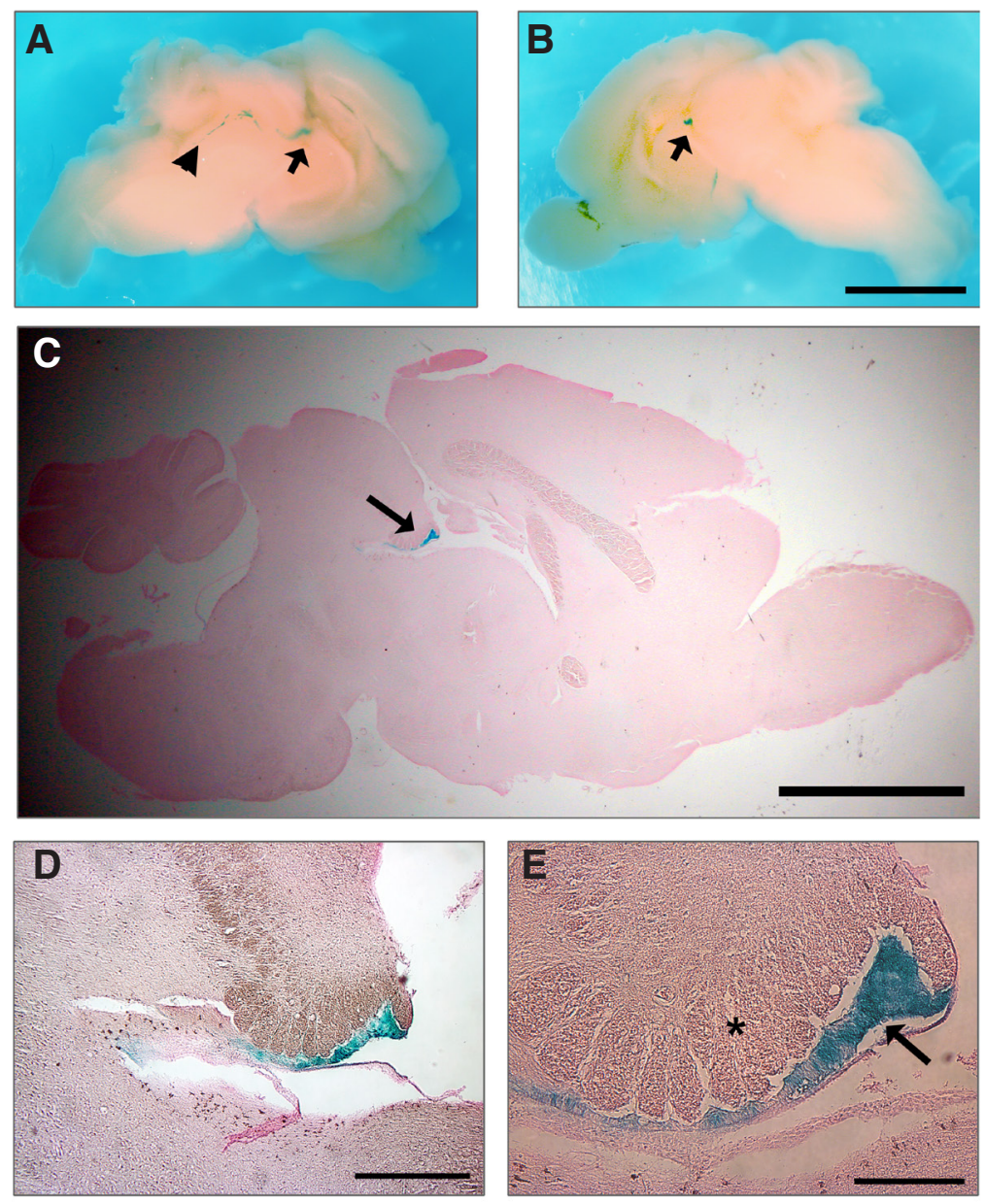

Fig 8. Nato3 expression is maintained in the subcommissural organ of old mice. (A,B) Brains of two-year-old mice were harvested, halved in a sagittal plane, and $X-G a l$ stained. From a global view, $X$-Gal staining appeared very tissue specific and was localized to the $I / I^{\text {rd }}$ and $/ V^{\text {th }}$ ventricles and to the cerebral aqueduct. Whole-mount $X$-gal staining revealed that the expression of the reporter is initiated anteriorly above the thalamic nuclei in the dorsal part of the IIrd ventricle (A) (see arrow), and then spreads posteriorly to the $4^{\text {th }}$ ventricle, (see arrowhead). The second half of the same brain also exhibited X-gal-positive cells in the other side of the subcommissural organ (B) (see arrow) and in the posterior part of the IIrd ventricle. (C-E) A histological section (at various magnifications) clearly depicted the expression of the Nato3 reporter in the subcommissural organ (arrow) beneath the posterior commissure (asterisk). Scale bars, $1 \mathrm{~mm}$ (A-C); $200 \mu \mathrm{m}$ (D); $100 \mu \mathrm{m}$ (E).

(Higashijima et al., 1997, Klar et al., 1992, Yulis et al., 1998).

The biological function of the subcommissural organ-Reissner's fiber complex remains unclear. It has been suggested that it is involved in osmoregulation, detoxification of the CSF, mechanoreception, and morphogenesis of the vertebral column and the spinal cord (Rodriguez et al., 1998). The absence of the subcommissural organ is associated with hydrocephalus in rats and mice suffering from congenital hydrocephalus, and in a number of knockout mice (Meiniel, 2007). Recent data suggest a role for subcommissural organ-secreted proteins that spread via the CSF and regulate neurogenesis (Guerra et al., 2015). In summary, we have identified two regions of the nervous system, namely, the spinal cord and brain, where ependymal cells are Nato3 positive throughout life and may affect neurogenesis by secreting diffus- ible molecules. Thus, novel biological functions of $\mathrm{Nato3}$ in the adult CNS remain to be deciphered.

\section{Materials and Methods}

\section{Animals}

All procedures were performed according to the guidelines of the Institutional Animal Care Committee (IACUC) of the Hebrew University, which is an AAALAC internationally accredited institute.

\section{Nato3 knockout mice}

The generation of Nato3 knockout mice was previously described and the targeting strategy was depicted in Fig S1 (Mansour et al., 2014). We completely, yet accurately removed the entire coding region and replaced it with a cassette containing a nuclear $\mathrm{LacZ}$ and a $\mathrm{NeO}^{R}$ selection marker. The construct was electroporated into C57BL/6N and 129SvEv hybrid ES cell lines and heterozygous mice were repeatedly backcrossed to C57BL/6 wild-type mice to obtain a pure genetic background.

\section{$X$-gal staining}

Whole embryos were stained as previously described (Gazit et al., 2004, Krizhanovsky and Ben-Arie, 2006, Schatz et al., 2014, Yu et al., 2013). After post-fixation, whole embryos were stored in $70 \%$ ethanol or cleared until transparent (Schatz et al., 2005), and photographed using an Olympus SZ-40 stereomicroscope and a Nikon Coolpix 5000 camera. For histological analysis, embryos or adult tissues were paraffin or OCT embedded and sectioned $(14 \mu \mathrm{m})$ using Microm HM325 microtome or Leica CM1850 cryostat, respectively. Sections were counterstained with eosin, and photographed under a Zeiss Axioskop2 microscope and an Olympus DP71 camera.

\section{Generation of anti-Nato3 antibodies}

A peptide (Ct-QFDERYQEVEGDE) representing amino acids 56-68 of the murine Nato3 protein (NCBI: NP_277057.1) was injected to goats, sera were harvested and ELISA-tested, and peptide-specific antibodies were affinity-purified. Notably, this antigenic region lies outsides the bHLH domain in a less conserved region, and is therefore species- and protein-specific. Currently, these anti-mouse Nato3 antibodies are commercially available as item \#EBP12182 at Everest Biotech (Oxfordshire, UK).

\section{Fluorescent immunohistochemistry}

Immunostaining was performed as previously described (Cho et al., 2014, Mansour et al., 2014, Mansour et al., 2011) with minor modifications. Slides with frozen sections were post-fixed in $100 \%$ cold acetone for $10 \mathrm{~min}$, air dried, washed in PBS, and incubated with a blocking solution (1xPBS, $4 \%$ heat-inactivated normal donkey serum, $0.1 \%$ Triton $\mathrm{X}-100)$ for $30 \mathrm{~min}$ at room temperature (RT). Slides were incubated with a diluted primary antibody overnight at $4^{\circ} \mathrm{C}$, after which they were washed in PBS, followed by a 1-hour incubation at RT with the diluted secondary antibody. Slides were washed in PBS and counterstained by $1 \mu \mathrm{g} / \mathrm{ml}$ DAPI (Roche) for $10 \mathrm{~min}$ at RT, washed in PBS, and mounted with Permafluor mounting medium (Thermo Scientific). Goat anti-Nato3 (Everest Biotech, Oxfordshire, UK) and donkey anti-goat IgG alexa fluor 488 (Jackson ImmunoResearch, PA, USA) were diluted 1:500 and 1:100, respectively. Rabbit anti-Arx (a kind gift from Kanako Miyabayashi, Kyushu University, Japan) and donkey anti-rabbit alexa flour 488 (Jackson ImmonoResearch, PA, USA) were diluted 1:500 and 1:500, respectively.

\section{Quantitative RT-PCR}

Total RNA was isolated from adult spinal cords using the Tri Reagent protocol provided by the manufacturer (Sigma). RNA samples were treated 
with RNase-free DNase (Ambion) for $50 \mathrm{~min}$ at $37^{\circ} \mathrm{C}$. Total RNA (500 ng) was reverse transcribed with random hexamer primers using the RevertAid First Strand cDNA Synthesis Kit (Thermo Scientific) according to the manufacturer's instructions. For quantitative real-time reverse transcription polymerase chain reaction (qRT-PCR), 20 $\mu \mathrm{L}$ amplification mixtures (KAPA SYBR green mix, KAPA biosystems) were prepared as specified by the company. Samples were examined separately using LightCycler 96 (Roch). The cycling conditions were as follows: pre-incubation at $95^{\circ} \mathrm{C}$ for 3 minutes, followed by 35 cycles at $95^{\circ} \mathrm{C}$ for 10 seconds, at $60^{\circ} \mathrm{C}$ for 20 seconds, and at $72^{\circ} \mathrm{C}$ of for 5 seconds. For a melting curve analysis, we used: $95^{\circ} \mathrm{C}$ for $5 \mathrm{sec}$, and at $65^{\circ} \mathrm{C}$ for $1 \mathrm{~min}$, and 10 acquisitions. Amplification of the products was verified by melting and amplification curves, and the correct size of the product was determined by gel separation.

The primers used were as follows: $\beta$-Actin (product size 104bp) forward 5'-AGATCTGGCACCACACCTTC-3' and reverse 5'-CTTTTCACGGTTGGCCTTAG-3'; Nato3 (100bp) forward 5'-GCTTGGCCATCGTCTACATT-3' and reverse 5'-GAGTGTCTCTTGGGCTCACC-3; FoxA2 (186bp) forward 5'- GTATGCTGGGAGCCGTGAAG -3' and reverse 5'- AGCCTGCGCTCATGTTGC -3'; Shh (98bp) forward 5'- CCAATTACAACCCCGACATC-3' and reverse 5'-GGCCAAGGCATTTAACTTGT-3'; and Arx (159bp) forward 5'-ATGAGGCTGGACCTGACAGA-3' and reverse 3'-GTCCAGGTAGGGGCTGAGAAG-5'.

\section{Acknowledgments}

This study was supported by Israeli Science Foundation grant 1051/15 to Nissim Ben-Arie.

\section{Author contributions}

The Nato3 knockout mouse was generated by Abed AF Mansour. The experiments were designed, performed, recorded, and analyzed by Sophie Khazanov, Abed AF Mansour, Yael Paz, Amit Hefetz, Ben Jerry Gonzales, and Yaara Netser. We thank Dr. Naomi Melamed-Book for her expert assistance with confocal imaging. The manuscript was written by Sophie Khazanov and Nissim Ben-Arie and was edited by the other authors.

\section{References}

CHO, G., LIM, Y., CHO, I.T., SIMONET, J.C. and GOLDEN, J.A. (2014). Arx together with FoxA2, regulates Shh floor plate expression. Dev Biol 393: 137-148.

DEL BIGIO, M.R. (2010). Ependymal cells: biology and pathology. Acta Neuropathol 119: $55-73$.

FU, H., QI, Y., TAN, M., CAI, J., HU, X., LIU, Z., JENSEN, J. and QIU, M. (2003). Molecular mapping of the origin of postnatal spinal cord ependymal cells: evidence that adult ependymal cells are derived from Nkx6.1+ ventral neural progenitor cells. J Comp Neurol 456: 237-244.

GAZIT, R., KRIZHANOVSKY, V. and BEN-ARIE, N. (2004). Math1 controls cerebellar granule cell differentiation by regulating multiple components of the Notch signaling pathway. Development 131: 903-913.

GUERRA, M.M., GONZáLEZ, C., CAPRILE, T., JARA, M., VIO, K., MUñOZ, R.I., RODRIGUEZ, S. and RODRIGUEZ, E.M. (2015). Understanding how the subcommissural organ and other periventricular secretory structures contribute via the cerebrospinal fluid to neurogenesis. Front. Cell. Neurosci. 9.

HAMILTON, L.K., TRUONG, M.K., BEDNARCZYK, M.R., AUMONT, A. and FERNANDES, K.J. (2009). Cellular organization of the central canal ependymal zone, a niche of latent neural stem cells in the adult mammalian spinal cord. Neuroscience 164: 1044-1056.

HIGASHIJIMA, S., NOSE, A., EGUCHI, G., HOTTA, Y. and OKAMOTO, H. (1997). Mindin/F-spondin family: novel ECM proteins expressed in the zebrafish embryonic axis. Dev Biol 192: 211-227.

HORNER, P.J., POWER, A.E., KEMPERMANN, G., KUHN, H.G., PALMER, T.D., WINKLER, J., THAL, L.J. and GAGE, F.H. (2000). Proliferation and differentiation of progenitor cells throughout the intact adult rat spinal cord. J Neurosci 20: 2218-2228.
JESSELL, T.M. (2000). Neuronal specification in the spinal cord: inductive signals and transcriptional codes. Nat Rev Genet 1: 20-29.

JOHANSSON, C.B., MOMMA, S., CLARKE, D.L., RISLING, M., LENDAHL, U. and FRISEN, J. (1999). Identification of a neural stem cell in the adult mammalian central nervous system. Cell 96: 25-34

KLAR, A., BALDASSARE, M. and JESSELL, T.M. (1992). F-spondin: a gene expressed at high levels in the floor plate encodes a secreted protein that promotes neural cell adhesion and neurite extension. Cell 69: 95-110.

KRIZHANOVSKY, V. and BEN-ARIE, N. (2006). A novel role for the choroid plexus in BMP-mediated inhibition of differentiation of cerebellar neural progenitors. Mech Dev 123: 67-75

LACROIX, S., HAMILTON, L.K., VAUGEOIS, A., BEAUDOIN, S., BREAULT-DUGAS C., PINEAU, I., LEVESQUE, S.A., GREGOIRE, C.A. and FERNANDES, K.J. (2014). Central canal ependymal cells proliferate extensively in response to traumatic spinal cord injury but not demyelinating lesions. PLoS One 9: e85916.

MANSOUR, A.A., KHAZANOV-ZISMAN, S., NETSER, Y., KLAR, A. and BEN-ARIE, N (2014). Nato3 plays an integral role in dorsoventral patterning of the spinal cord by segregating floor plate/p3 fates via Nkx2.2 suppression and Foxa2 maintenance. Development 141: 574-584.

MANSOUR, A.A., NISSIM-ELIRAZ, E., ZISMAN, S., GOLAN-LEV, T., SCHATZ, O. KLAR, A. and BEN-ARIE, N. (2011). Foxa2 regulates the expression of Nato3 in the floor plate by a novel evolutionarily conserved promoter. $\mathrm{Mol}$ Cell Neurosci 46: 187-199.

MEINIEL, A. (2007). The secretory ependymal cells of the subcommissural organ: which role in hydrocephalus? Int J Biochem Cell Biol 39: 463-468.

NISSIM-ELIRAZ, E., ZISMAN, S., SCHATZ, O. and BEN-ARIE, N. (2013). Nato3 integrates with the Shh-Foxa2 transcriptional network regulating the differentiation of midbrain dopaminergic neurons. J Mol Neurosci 51: 13-27.

OLSSON, R. (1993). Reissner's Fiber Mechanisms: Some Common Denominators In The Subcommissural Organ: An Ependymal Brain Gland, (ed. OKSCHE, A.RODRíGUEZ, E. and LLEBREZ, P.). Springer Verlag., Berlin, pp.33-39.

ONO, Y., NAKATANI, T., MINAKI, Y. and KUMAI, M. (2010). The basic helix-loop-helix transcription factor Nato3 controls neurogenic activity in mesencephalic floor plate cells. Development 137: 1897-1906.

PETRACCA, Y.L., SARTORETTI, M.M., DI BELLA, D.J., MARIN-BURGIN, A., CARCAGNO, A.L., SCHINDER, A.F. and LANUZA, G.M. (2016). The late and dual origin of cerebrospinal fluid-contacting neurons in the mouse spinal cord. Development 143: 880-891.

RIBES, V., BALASKAS, N., SASAI, N., CRUZ, C., DESSAUD, E., CAYUSO, J., TOZER, S., YANG, L.L., NOVITCH, B., MARTI, E. et al., (2010). Distinct Sonic Hedgehog signaling dynamics specify floor plate and ventral neuronal progenitors in the vertebrate neural tube. Genes Dev 24: 1186-1200.

RODRIGUEZ, E.M., RODRIGUEZ, S. and HEIN, S. (1998). The subcommissural organ. Microscopy Res. Tec. 41: 98-123.

SCHATZ, O., GOLENSER, E. and BEN-ARIE, N. (2005). Clearing and photography of whole mount X-gal stained mouse embryos. Biotechniques 39: 650, 652, 654 passim.

SCHATZ, O., LANGER, E. and BEN-ARIE, N. (2014). Gene dosage of the transcription factor Fingerin (bHLHA9) affects digit development and links syndactyly to ectrodactyly. Hum Mol Genet 23: 5394-5401.

SEGEV, E., HALACHMI, N., SALZBERG, A. and BEN-ARIE, N. (2001). Nato3 is an evolutionarily conserved bHLH transcription factor expressed in the CNS of Drosophila and mouse. Mech Dev 106: 197-202.

YU, K., MCGLYNN, S. and MATISE, M.P. (2013). Floor plate-derived sonic hedgehog regulates glial and ependymal cell fates in the developing spinal cord. Development 140: 1594-1604.

YULIS, C.R., MOTA, M.D., ANDRADES, J.A., RODRIGUEZ, S., PERUZZO, B., MANCERA, J.M., RAMIREZ, P., GARRIDO, M., PEREZ-FIGAREZ, J.M., FERNANDEZ-LLEBREZ, P. et al., (1998). Floor plate and the subcommissural organ are the source of secretory compounds of related nature: comparative immunocytochemical study. J Comp Neurol 392: 19-34. 


\section{Further Related Reading, published previously in the Int. J. Dev. Biol.}

The involvement of three signal transduction pathways in botryllid ascidian astogeny, as revealed by expression patterns of representative genes

Amalia Rosner, Gilad Alfassi, Elizabeth Moiseeva, Guy Paz, Claudette Rabinowitz, Ziva Lapidot, Jacob Douek, Abraham Haim and Baruch Rinkevich

Int. J. Dev. Biol. (2014) 58: 677-692

http://dx.doi.org/10.1387/ijdb.140114ar

What Hydra can teach us about chemical ecology - how a simple, soft organism survives in a hostile aqueous environment Tamar Rachamim and Daniel Sher

Int. J. Dev. Biol. (2012) 56: 605-611

http://dx.doi.org/10.1387/ijdb.113474tr

Mouse models to study inner ear development and hereditary hearing loss

Lilach M. Friedman, Amiel A. Dror and Karen B. Avraham

Int. J. Dev. Biol. (2007) 51: 609-631

http://dx.doi.org/10.1387/ijdb.072365lf

The importance of the posterior midline region for axis initiation at early stages of the avian embryo

Oded Khaner

Int. J. Dev. Biol. (2007) 51: 131-137

http://dx.doi.org/10.1387/ijdb.062226ok

Early stages of neural crest ontogeny: formation and regulation of cell delamination Chaya Kalcheim and Tal Burstyn-Cohen

Int. J. Dev. Biol. (2005) 49: 105-116

http://dx.doi.org/10.1387/ijdb.041949ck

High proliferation rate characterizes the site of axis formation in the avian blastulastage embryo

N Zahavi, V Reich and O Khaner

Int. J. Dev. Biol. (1998) 42: 95-98

http://dx.doi.org/10.1387/ijdb.9496791

Immunohistochemical analysis of the segregation process of the quail germ cell lineage M Ginsburg M, J Hochman and H Eyal-Giladi

Int. J. Dev. Biol. (1989) 33: 389-395

http://www.ijdb.ehu.es/web/paper.php?doi=2702123
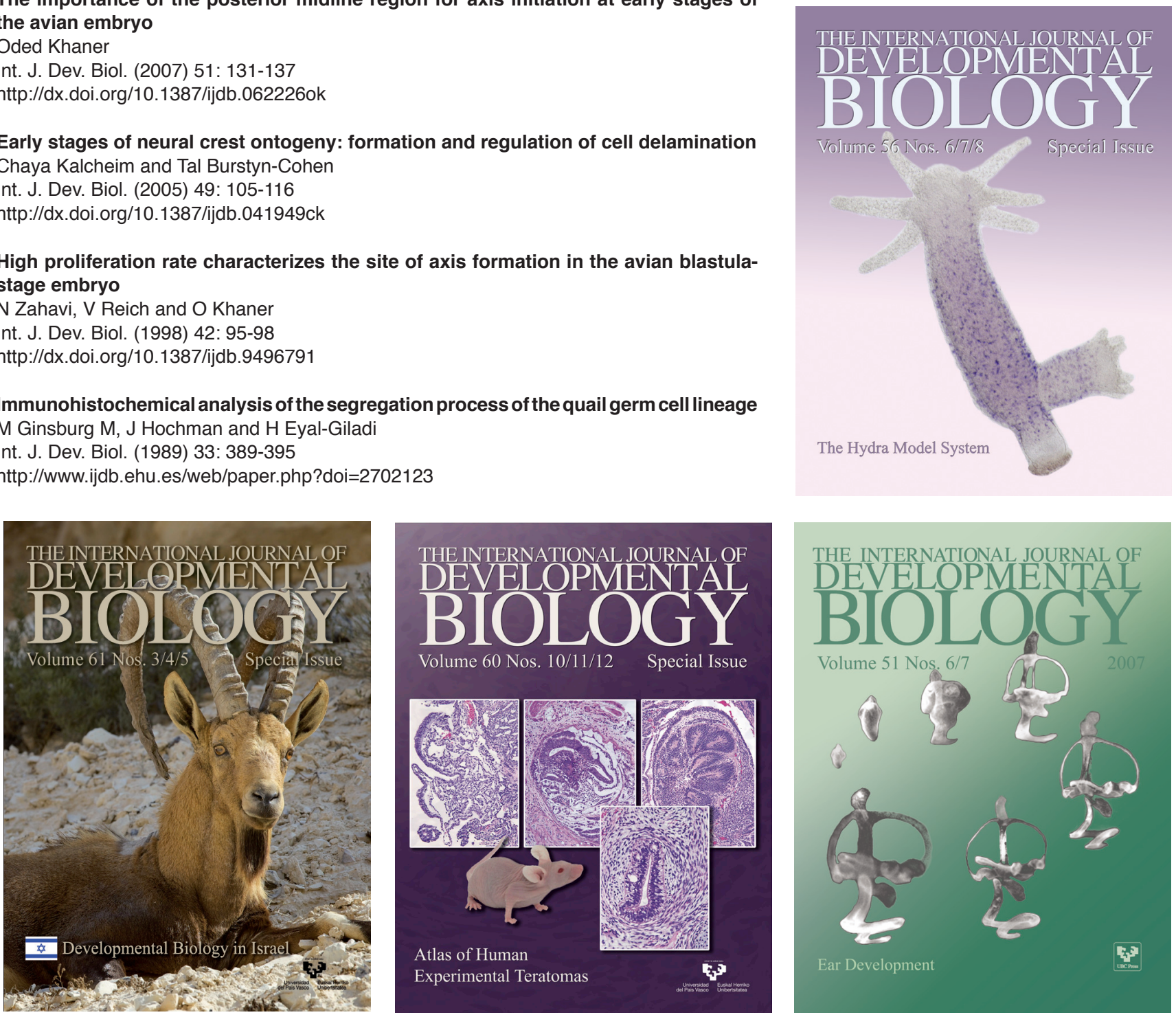